\title{
The Government Policies Effect on Initiation and Implementation of the Project: A Conceptual Model
}

\author{
Fitria Astuti Firman ${ }^{1 *}$, Ine Minara Ruky ${ }^{2}$, Ratih Dyah Kusumastuti ${ }^{3}$ and Harris Turino \\ Kurniawan ${ }^{4}$ \\ 1,3,4 Department of Management, Faculty of Economics \& Business, Universitas Indonesia, Kampus UI Depok, 16424, West Java, \\ Indonesia \\ ${ }^{2}$ Department of Economics, Faculty of Economics \& Business, Universitas Indonesia, Kampus UI Depok, 16424, West Java, Indonesia
}

\begin{abstract}
Objective - An urgency to investigate the impact of government policies on project performance through strategic management perspective is motivated by the gap of knowledge on a relationship between government policies and project. This paper proposes a conceptual model for further empirical research in the future. Six latent variables and ten hypotheses are developed through reviewing some literature in three following research avenues: Entrepreneurship, Strategic Management, and Project Management.

Methodology - In order to observe a logical fitness of model development on government policies influences to firm activities, a specific context is chosen, namely the Indonesian renewable energy power generation. The last research avenue is strongly related to the research context. Further empirical study is required, and a discussion on it is presented in this paper.

Findings - This paper emphasizes that project activities should be strategically managed since those support the achievement of business performance.

Novelty - The study will bring benefits to the three following aspects: theoretical, managerial and regulatory aspects. Type of Paper: Review
\end{abstract}

Keywords: Capability; Entrepreneurial orientation; Government policies; Project performance; Resource orchestration JEL Classification: H11, M21

\section{Introduction}

There is an urgency to investigate the impact of government policies on project performance through the lens of strategic management. Nowadays, organizations have increasingly used projects to achieve their business goals (Morris \& Jamieson, 2004; Papke-Shields, Beise, \& Quan, 2010). In this regard, project management becomes critical for organization. In managing projects, organizations and their environment are affected by increasing complexity, uncertainty, and ambiguity factors (Pich, Loch, \& Meyer, 2002). That situation has been realized by project management communities. They realize that in the end, environments

\footnotetext{
* Paper Info: Received: October 31, 2016

Accepted: April 14, 2017

* Corresponding author:

E-mail: fitria.fahlefi@gmail.com

Affiliation: Department of Management, Faculty of Economics \& Business, Universitas Indonesia
} 
will affect the performance of project. Unfortunately, less research are showing the relationship between environments and projects (Pinto \& Winch, 2016).

In highly regulated industry, it is often that projects are initiated by the Government through their policies. For an example, power market deregulation in some countries has bring opportunities to develop power generation projects for the business sector (Joskow, 1997; Pintz \& Korn, 2005; Sine, Haveman, \& Tolbert, 2005). Other example, policies on climate change have motivated the business sector to develop renewable energy projects (Corfee-morlot et al., 2012). Some research has been conducted to see the impact of government policies on projects (e.g. Corfee-morlot et al., 2012; Jager \& Rathmann, 2008; Peidong et al., 2009; Polzin, Migendt, Täube, \& Flotow, 2015). However, those research are conducted in the perspective of economics which assume that all business players are rational actors who will gain economic benefits from supportive government policies through opportunity exploitation.

In reality, business players don't always see government policies as opportunities and take benefits from those policies. Government policies, such as energy policies, have two opposite aspects - risk and expected return which are considered by entrepreneurs (Wustenhagen \& Menichetti, 2012). Thus, it is important for entrepreneurial corporate to understand how to manage the risk and achieve high return when government policies have significant impacts on their business activities. Pinto \& Winch (2016) emphasize that the relationship between government policies and project is still unsettled - a black box which is need to be further investigated. They suggest that strategic management perspective can bridge the relationship between government policies and projects. Research through strategic management is needed to investigate in more detail on internal attributes of firms and processes which influence the projects. Unfortunately, there are still less research in strategic management that discuss project management (Pinto \& Winch, 2016), while it is important for corporates to align the front end of projects with the overall strategy of their organization (Morris \& Jamieson, 2004).

Considering the above situation, this paper aims to investigate the impacts of government policies on projects' initiation and implementation by building a conceptual model. Thus, this paper highlights the importance to link Strategic Management and Project Management. Strategic Management School of Thought in Project Management research mainly focuses on investigating various criteria of project success and factors that determine the success (Turner, Anbari, \& Bredillet, 2013), while Strategic Management is the field of study that concerns about how firms can outperform others through strategy formulation and implementation (Hitt, Ireland, Camp, \& Sexton, 2001). Strategy formulation focuses on how initiative and strategy of organizations are generated to respond to environmental changes (Helfat et al., 2007; Teece, 2007). Strategy implementation focuses on objectives achievement and control in implementing strategy, where project is a part of strategy implementation scope. However, both Strategic Management and Project Management are missing in explaining what factors drive the project initiation and what firm's internal attributes influence the performance of project. In sum, both have less attention in explaining on how organization's business strategy and resources are translated at the project level.

A conceptual model presented in this paper allows an analysis on the internal attributes and processes of firms which support the achievement of successful project performance. Further, this paper brings an analysis model on how government policies as institutional context affect the project performance to answer the challenge emphasized by Pinto and Winch (2016). In strategic management perspective, government policies are considered as institutional capital - the firm's unique resources which are embedded in its institutional environment (Bresser \& Millonig, 2003; Oliver, 1997). This paper also brings a consideration on how government policies can stimulate the project through entrepreneurship concept. The relationship between government policies and entrepreneurship has been addressed by some researchers in entrepreneurship field (e.g. Eckhardt \& Shane, 2003; Minniti, 2008; Sine et al., 2005). Yet, there are less attention in literature to identify specific variables to be empirically measured.

A specific research context is chosen to see a fitness between a logical thinking of model and current phenomena in the industry. A renewable energy power generation industry in Indonesia is selected. Under 
current Energy and Electricity Laws, Indonesia allows a business sector to provide electricity to be sold to the electricity stated owned company - PT PLN (Persero), as a monopoly company on electricity distribution and transmission. Since 2002, the Government of Indonesia has stimulated a utilization of renewable energy for power generation, and a target of Indonesian Government of a minimum $23 \%$ to utilize renewable energy in 2025 (GOI, 2014) make even a stronger market creation for renewable energy industry. However, current situation shows that renewable energy programs and projects are still far from the target, and moreover, some renewable energy power plant projects are delayed or even fail.

The remainder of the paper is organized as follows. Methodology is presented in Section 2, followed by Results in Section 3. Discussion is then presented in Section 4.

\section{Methodology}

In order to address the aim - to identify the research gap and propose the conceptual model, this paper review theories in strategic management field, namely institutional theory and strategic entrepreneurship concept. Strategic entrepreneurship concept is rooted from entrepreneurship concept and resource-based theory (RBT). This paper also reviews literature of project management, especially literature of strategic management school of thought to seek their bottom line. The review is presented in the following sub-sections.

Further, since government policies are highly subjective to the context, it is important to see a logical fitness of the concepts taken from literature with current phenomena in the industry. For that purpose, a specific industry is chosen as the research context. The selection is conducted by considering the industry which is highly influenced or shaped and driven by Government policies. In this paper, renewable energy based power generation industry in Indonesia is selected. A review of that industry is conducted through government publications and research paper on energy policies.

Papers are searched through databases, namely JSTOR and SCOPUS. Some keywords for the searching are government policies, entrepreneurial orientation, resource orchestration, project performance, capabilities and strategic entrepreneurship. Those keywords are used in a combination by using Boolean operators (AND, OR). Backward referencing from relevant papers are also conducted, and documents from government are also obtained to review the industry. In total, we analyze the abstracts of about 900 papers and documents. In the end, there are 315 relevant papers and documents, and 71 papers of them are cited in this current paper.

\subsection{Entrepreneurship and Strategic Entrepreneurship Concepts}

Entrepreneurship is defined as a process of identifying and pursuing entrepreneurial opportunities, both for new and existing firms to gain wealth creation (Lumpkin \& Dess, 1996).

For decades, entrepreneurship is measured by a construct of entrepreneurial orientation. This construct is first identified based on the work of Mintzberg (1973), and then it is developed based on the famous work of Miller (1983) (Covin \& Wales, 2012). Entrepreneurship scholars argue that entrepreneurship is a critical feature to achieve a high firm performance (Lumpkin \& Dess, 1996). Yet, previous research on entrepreneurship have not shown how to achieve that high performance.

In strategic management field, the concept of entrepreneurship is then expanded into strategic entrepreneurship, whereby entrepreneurship is connected to both opportunities exploration and exploitation, and strategic thinking and action (Hitt et al., 2001; Ireland, Hitt, \& Sirmon, 2003). A model of strategic entrepreneurship introduced by Ireland, Hitt \& Sirmon (2003) has four following constructs: (1) the entrepreneurial mindset, culture, and leadership; (2) the strategic management of organizational resources; (3) application of creativity; and (4) development of innovation. Those constructs influence the firm's achievement of competitive advantage and wealth creation.

The previous model of strategic entrepreneurship is challenged on its robustness, scope and multilevel analysis (Sirmon, Hitt, Ireland, \& Gilbert, 2011). Thus, in order to answer that challenge, Hitt et al. (2011) expand the model into input-process-output model. In this model, environmental factors, organizational 
resources and individual resources are defined as inputs. Further, as a process, firm's effort in managing their resources is defined. The process is followed by the resource orchestration framework. Finally, creating value or competitive advantage and creating wealth and other benefits are defined as outputs (Hitt, Ireland, Sirmon, \& Trahms, 2011).

The current model of strategic entrepreneurship is more comprehensive to analyze the impact of external factor on firm's performance. By applying resource orchestration concept, the model allows the analysis of firm's internal attribute on firm resources and capabilities - an expanded concept on RBT. According to RBT, firm can achieve the competitive advantage by having valuable, rare, inimitable and non-substitutable resources (Barney, 1991). Resource orchestration concept emphasizes that having resources are not enough without strategic actions from the firm. Therefore, that concept suggests a set of process of resource structuring, bundling and leveraging (Sirmon et al., 2011).

\subsection{Institutional Theory}

There are a lot of paradigms which have been developed by institutionalists (Scott, 1987). The paradigm used in explaining strategic management issues is neo-institutional theory which focuses on economics and organization theory. This institutional theory allows an analysis of situation where firms as organizations are influenced by their environment. Further, this environment gives a certain impacts to firm's competitive advantage (Bresser \& Millonig, 2003).

Rooted from that institutional theory, a concept of institutional capital is developed with a fundamental argument that economic choices (including choices of resources) are constrained not only by factor limits defined in neoclassical economic model (e.g. the technological, information and income), but also by socially constructed limits (e.g. norms, habits, and customs) (Oliver, 1997). By including institutional theory in the analysis, firms will be able to recognize their situation on institutional constraints which benefits their strategic choices (Peng, Sun, Pinkham, \& Chen, 2009). In this regard, combining institutional theory and the concept of strategic entrepreneurship is critical for developing the model analysis.

Policies are identified as formal institutions and supportive pillars which can influence firm performance (Peng et al., 2009). Government policies are viewed as a capital that can produce pressures and punishments (Bresser \& Millonig, 2003), and at the same time, policies provide opportunities to firm to develop their resources and capabilities (Platje, 2008). Further, in the context of industry creation, the policies can be viewed as institutional capital to gain legitimacy for firms to do their business activities (Aldrich \& Fiol, 1994), and reduce uncertainties, especially in emerging markets (Tracey \& Phillips, 2011). Institutional theory is often used in many research which are related to emerging economics.

\subsection{Project Management: Strategic Management School of Thought}

Over two decades, strategic management literature has emerged on project management (Ulri, 2000 as cited in Jugdev \& Müller, 2005). The process produces a school management of thought that concerns about project success factors and criteria (Cooke-Davies, 2002; Turner et al., 2013). It shows that project management should have not be seen as tactical value, but as strategic value to achieve the business goal (Jugdev \& Müller, 2005; Turner et al., 2013). Projects are needed to create changes in organizations. Many previous literature show that project is a 'temporary organization' that deliver changes to 'the permanent organization' ((e.g. Silvius, Schipper, Planko, van den Brink, \& Kohler, 2012).

A perspective of project as a temporary organization grows based on the Theory of Temporary Organization (Pinto \& Winch, 2016) to differentiate between firm as a permanent organization and project as an additional organization which is part of that firm (Svejvig \& Andersen, 2015). The perspective receives some critiques. In 1994, Peter Morris introduced the Management of Projects (MoP) as a critique to a temporary perspective. An approach of seeing project as a temporary organization has led to a failure to provide an analysis on project initiation (which may be started at the business level) and project development stages. It has also lead a failure 
to analyze some critical elements of projects, such as leadership, people, learning, and improvement (see Morris, 2013), while it is highlighted that a business strategy should be able to be translated into a project level (Morris \& Jamieson, 2004). In this regard, there is a need to extend a temporal scope of project and analyze an evolvement of project practices in the past, present and future (Engwall, 2003). A comprehensive understanding of the principle activities of project management and boundaries for project success is then given by the Three Domain Perspective (Pinto \& Winch, 2016). That perspective introduced by Winch (2014) which shows the interface between the alliances of organizations that contribute to the overall management of project. The model differs project capabilities which are brought by organizations from the overall project efforts (Winch, 2014). Firms should see a project as a function of organization (Aubry, Sicotte, Drouin, Vidot-Delerue, \& Besner, 2012). Research on Project Management Office (e.g. Aubry, Hobbs, \& Thuillier, 2007; Dai \& Wells, 2004) has brought other understanding that emphasizes the relationship between an overall strategy of organization and its project (Killen, Jugdev, Drouin, \& Petit, 2012).

In sum, the bottom line among entrepreneurship and strategic entrepreneurship, institutional theory and project management is that project should be seen as a function of firm to achieve a business goal in exploring and exploiting opportunities which can be influenced by firm environment, including government policies. The influence process can be understood by identifying internal attributes and process in that firm. An integrated analysis is necessary to understand on how corporate strategy is translated into a strategy of project in order to achieve a success of project in gaining the business goal.

\section{Results}

Six measurable variables are identified from three research venues on entrepreneurship, institutional theory and project management as follow: government policies, entrepreneurial orientation, resources accumulation and acquisition, network capability, project management capability and perceived investment performance as can be seen in Figure 1. Relationships among those constructs are built based on a strategic entrepreneurship framework developed by Hitt et al. (2011). Government policies is defined as inputs along with entrepreneurial orientation. Government policies represents firm environment, while entrepreneurial orientation represents firm resources.

Government policies refers to specific policies implemented by the Government in a specific industry which may affect the performance of the firm. Entrepreneurial orientation is defined as strategy making process which process is a fundamental direction for firm's entrepreneurial decision and action (Rauch, Wiklund, Lumpkin, $\&$ Frese, 2004). This paper argues that entrepreneurial orientation is a reflection of entrepreneurial leadership, entrepreneurial mindset and culture. Entrepreneurial orientation can be measured through firm's behavior on risk taking, innovativeness, pro-activeness, competitive aggressiveness and autonomy (Covin \& Slevin, 1989; Lumpkin \& Dess, 1996; Miller, 1983).

Further, in the strategic entrepreneurship model, process is defined as a process of structuring, bundling and leveraging resources (Hitt et al., 2011; Ireland et al., 2003; Sirmon et al., 2011). The process is represented by the variable of resources accumulation and acquisition as a process of firm to structure their resources. Other variables of network capability and project management capability represent firm activities to bundle and leverage their resources.

Perceived investment performance is a variable which has a broader definition of project success. It is the success of entrepreneurs in investing their money on a project which can be perceived differently by stakeholders involved in that project. Thus, it should be measured beyond the iron triangle of project success - cost, time and quality. It is suggested that a variable of perceived investment performance is measured by multidimensional approach, considering not only cost, time and money, but also firm's business success, impact on customers, and the future of project (its sustainability) (Shenhar, Dvir, Ofer, \& Maltz, 2001).

The development of research model also considers a logical framework of current phenomena in a specific industry. A highly regulated industry of renewable power sector in Indonesia is chosen for that purpose. A market deregulation on power sector, has opened opportunities to business sector to sell electricity, including 
renewable energy based electricity. This opportunity is then captured by corporates or firms. Obligated by a regulation, firms should form an independent power producer (IPP) - which in the context of Indonesia is defined as "a special purpose company (SPC) which is formed by sponsor(s) or consortium to execute a power purchase agreement with PLN (an electricity state owned company) and to develop, build, own, and operate power plant" (PLN, 2013). This IPP is a project based company that translating its corporate strategy into a project strategy.

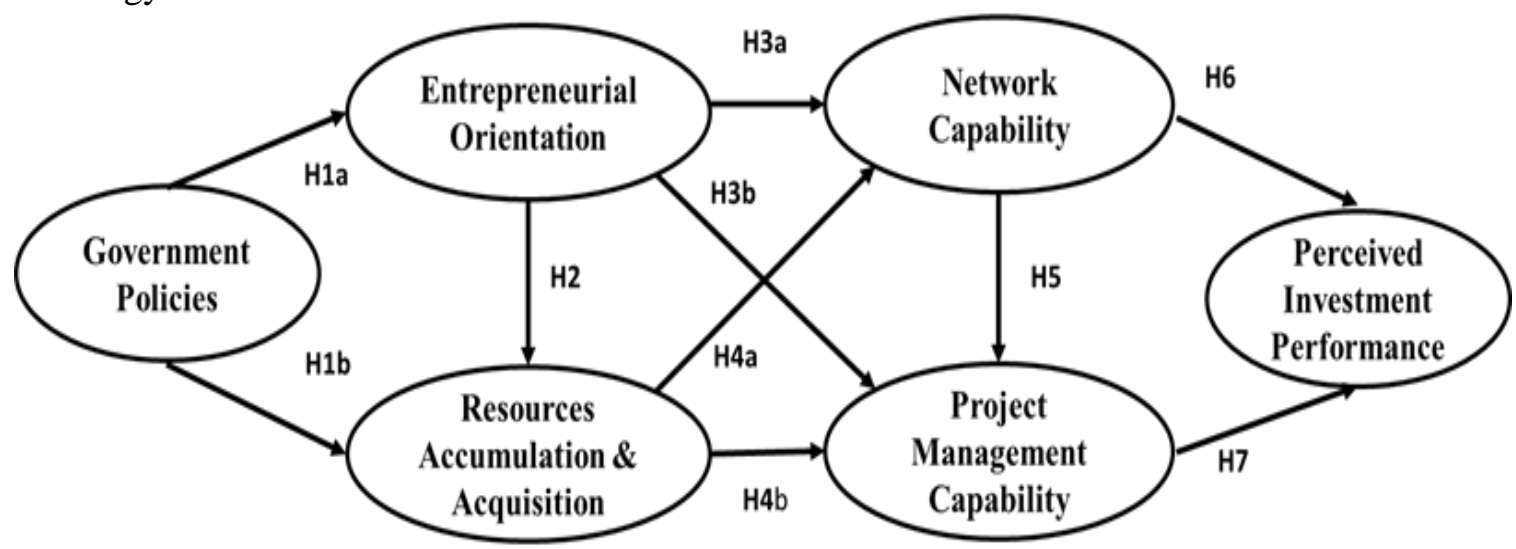

Figure 1. The proposed research model

The study conducted by Shirokova and Sokolova (2013) shows that institutional environment can increase entrepreneurial orientation of the firm. Interestingly, their study shows that not all institutional capitals support the orientation. Relationship between institutional environment and entrepreneurial orientation could be specific to the context which leads to a need for further investigation (Shirokova \& Sokolova, 2013). A market deregulation in Indonesian power sector has led to a business sector involvement in generating electricity.

Further, a target on renewable energy utilization has made a market creation for renewable energy power generation. Assuming that the Indonesian Government has done some efforts to achieve the target on renewable energy power industry through their supporting policies, then it can be argued that government policies will lead to a stronger entrepreneurial orientation. Thus:

H1a: Government policies will positively affect an entrepreneurial orientation.

In parallel, when firm decides to take their opportunities, government policies are seen as institutional capitals which can influence firm performance (Bresser \& Millonig, 2003; Oliver, 1997). Institutional factors have significant impacts on firm efforts on resources and strategies selection (Peng, 2003; Yamakawa, Peng, $\&$ Deeds, 2008). Regulations may reduce perceived risk, and at the same time increase a willingness and ability of entrepreneurs to act (Sine et al., 2005). Thus, it is argued that government policies will affect firm in managing its resources, and can be stated as follow:

H1b: Government policies will positively affect resource accumulation and acquisition.

Further, some research show that there is an interaction between entrepreneurial orientation and resources in order to achieve good firm performance. Entrepreneurial orientation has an influence on knowledge based resources (e.g. marketing capabilities and technological capability) (Wiklund \& Shepherd, 2003), and also strategic learning capability (Chirico, Sirmon, Sciascia, \& Mazzola, 2011). It is then argued that entrepreneurial orientation can also influence a strategic action of firm in managing its resources, since entrepreneurial orientation provide an essential basis for firm decisions and actions (Rauch et al., 2004). Thus: $\mathrm{H} 2$ : Entrepreneurial orientation will positively affect resource accumulation and acquisition.

As an input, entrepreneurial orientation is an intangible resources which cannot be gained from the market (Lee, Lee, \& Pennings, 2001). Based on the concept of resources orchestration (Sirmon et al., 2011; Sirmon, Hitt, \& Ireland, 2007), resources should be bundled and leveraged in order to exploit the opportunities and gain performances. Thus, entrepreneurial orientation will affect firm capabilities. 
Based on previous research, two following capabilities are identified: network capability and project management capability. Since entrepreneurial orientation is about pursuing opportunities, firm needs to seek other resources which not all can be gained internally. Network is critical to obtain other resources, such as financial, information and reassurance (Birley, 1985) and to reduce asymmetry information (Shane \& Cable, 2002; Uzzi \& Lancaster, 2003). Network capability is a firm's ability to initiate, maintain, and utilize relationships with stakeholders to gain resources which are available in markets (Chen \& Tan, 2009; Mitrega, Forkmann, Ramos, \& Henneberg, 2012; Walter, Auer, \& Ritter, 2006). Thus:

H3a: Entrepreneurial orientation will positively affect network capability.

When the firm has an ambition to achieve its business goal, this ambition should vertically translated into a project level (Morris \& Jamieson, 2004). Project management capability is not frequently discussed in business level strategy, while performance of project is actually connected to business process (Hillson, 2003; Jurisch \& Palka, 2014), and business performance (Ethiraj, Kale, Krishnan, \& Singh, 2005; Hadaya, Cassivi, \& Chalabi, 2012), especially in project based firm where project is viewed as a strategic project to achieve business performance (Shenhar et al., 2001). Thus, it is argued that firm with a strong entrepreneurial orientation will lead to higher capability in managing its project, and it can be stated as follow:

H3b: Entrepreneurial orientation will positively affect project management capability.

Further, based on resource orchestration framework, a firm action to structure its resources should be followed by the actions on resources bundling and capability leveraging (Sirmon et al., 2011, 2007). It is then argued that network capability and project management capability can be gained through the persistent efforts of firm in bundling and leveraging its resources.

Through an accumulation and acquisition process, firm will gain a high amount of resources which can be utilized to reconfigure new resource combinations. Those new resource combinations can be utilized to explore and exploit resources in the network. As for example, a prototype produced from resource accumulation can be used to gain financial resources from the network. Other example is reputation. Good reputation accumulated by firm can build trust and maintain the relationship. Those resources accumulation will affect the firm ability to do networking activities, thus:

H4a: Resource accumulation and acquisition will positively affect network capability.

In the same framework, it is argued that resource accumulation and acquisition will also affect other capabilities of firm, including capabilities in project level. Project management capability is a firm capability to manage firm's assets in project level in order to gain competitive advantage (Jugdev, Mathur, \& Fung, 2007), thus it can be stated that:

H4b: Resource accumulation and acquisition will positively affect project management capability.

Furthermore, it is also argued that project management capability is influenced by network capability. Network capability is conceptualized as a firm-level concept (Kale, Singh, \& Perlmutter, 2000) to gain external resources (Walter et al., 2006). Most of the time, project managers face difficulties to allocate resources since the resources are being temporarily absent or even the firm doesn't have the resources. The network capability is argued can influence the time and cost in gaining resources from the market and in the end, increase the capability of firm in managing its project. Thus:

H5: Network capability will positively affect project management capability.

Finally, based on resource orchestration framework, both network capability and project management capability are generated from persistent efforts of firm in bundling and leveraging its resources and capabilities. Those two capabilities are expected to influence the firm performance, which in this paper is referring to perceived investment performance.

Previous studies show that network capability has positive relationships with performance, such as supplier and buyer performances (Henseler, 2009), sales growth, customer orientation and financial performance (Human \& Naudé, 2009), and innovation performance (Zeng, Xie, \& Tam, 2010). Other studies show that network capability can also act as a moderator between resources and performance (e.g. Walter et al., 2006). 
This paper argues that network capability will influence perceived investment performance and can be stated as follow:

H6: Network capability will positively affect perceived investment performance.

In the same vein, project management capability is also found to have a positive relationship with project performance (e.g. Ethiraj et al., 2005; Jugdev \& Thomas, 2002; Jurisch \& Palka, 2014; Zwikael, Shimizu, \& Globerson, 2005). Thus, it is argued that:

H7: Project management capability will positively affect project management capability.

In sum, it is found that six variables identified in literature has produced ten hypotheses based on a logical framework of strategic entrepreneurship and pervious literature in three research avenues on entrepreneurship, institutional theory, and project management.

\section{Discussion}

The conceptual model is proposed to be measured by analyzing a specific industry where policies and regulations have significance impacts to strategy formulation and implementation of the firm. This paper uses a highly-regulated industry of renewable power industry with a unit analysis of IPPs in Indonesia. IPPs are project based companies dedicated to build and maintain renewable energy power generation, and at the same time selling the electricity to PLN. The model is suggested to be measured by using questionnaire as a tool. The proposed model allows us to investigate a multilevel-analysis on corporate level to investigate the influence of government policies to entrepreneurial behavior and resource accumulation and acquisition, while at the firm level and project level, the analysis can be conducted through capabilities owned by IPPs.

Ten developed hypotheses will give knowledge on firm specific resources and capabilities needed in a highly-regulated industry in order to manage the influence of external factor influences. The model give a comprehensive figure on how corporate resources are translated into the project level. Interestingly, the model also shows an interaction between two capabilities which allows us to analyze a process between a business level and a project level. The approach used in the model breaks a traditional project management perspective where project is viewed as a temporary organization and it has a short-term period.

This paper emphasizes that project activities should be strategically managed since those support the achievement of business performance. In this regard, firm needs to focus on how to achieve business goals and winning in the market competition (Shenhar et al., 2001). In the case of IPP industry, project is defined as a long term process involving serial activities on conception and feasibility studies, project planning, bidding and contracting, and project implementation (Ling \& Lau, 2002) or it can be said from the project preparation until the product utilization (electricity selling) during the power plant life-cycle.

The data analysis is proposed to be conducted by using a statistical technique that allows multivariate data analysis as needed for the model measurement. The model has dependent variables for one regression analysis, which at the same time become independent variables for others. A structural equation modelling (SEM) is suggested to be used (Diamantopoulos, 1994; Hair Jr., William, Babin, \& Anderson, 2014). That analysis tool is chosen since SEM combines a measurement model and a structural model in one statistical test (Garver \& Mentzer, 1999).

This paper presents a conceptual model for further empirical research, which integrates three research avenues on Strategic Management (i.e. strategic entrepreneurship and institutional theory), Project Management, and Public Policies on a specific context. The model is proposed to be measured in highly regulated industry (e.g. a power business sector which is a context proposed in this paper). In this regard, reviewing literature on energy policies for power business sector is conducted.

Further empirical work on the conceptual model will give significance impacts on three following aspects: theoretical, managerial and regulatory aspects. Theoretically, the research will answer the challenge of knowledge gap on a relationship between government policies and project, and contribute to project management literature. It also contributes to strategic management literature by strengthening the concept of 
strategic entrepreneurship and resource orchestration. In addition, the model also contributes to link resources and capabilities at business and project levels.

A managerial contribution is gained by identifying specific resources and capabilities in renewable energy based power generation industry which contribute to the success of IPP business. It should be noted that capabilities are very specific to the context and not all capabilities contributes to the competitive advantage, while capabilities are costly and time consuming (Ethiraj et al., 2005). Finally, it is expected that the research can generate inputs from business sector for an improvement on policies design to accelerate the penetration of renewable energy in power generation industry.

\section{Acknowledgements}

We would like to thank Universitas Indonesia for the publication grant.

\section{References}

Aldrich, H. E., \& Fiol, C. M. (1994). Fools Rush in ? the Institutional Context of Industry Creation. Academy of Management Review, 19(4), 645-670.

Aubry, M., Hobbs, B., \& Thuillier, D. (2007). A new framework for understanding organisational project management through the PMO. International Journal of Project Management, 25(4), 328-336.

Aubry, M., Sicotte, H., Drouin, N., Vidot-Delerue, H., \& Besner, C. (2012). Organisational project management as a function within the organisation. International Journal of Managing Projects in Business, 5(2), 180-194.

Barney, J. (1991). Firm Resources and Sustained Competitive Advantage. Journal of Management, 17(1), 99-120.

Birley, S. (1985). The Role of Networks in the Entreprenuerial Process. Journal of Business Venturing, 1, 107-117.

Bresser, R. K. F., \& Millonig, K. (2003). Institutional Capital: Competitive Advantage in Light of the New Institutionalism in Organization Theory. Schmalenbach Business Review, 55, 220-241.

Chen, W., \& Tan, J. (2009). Understanding Transnational Entreprenuership Through a Network Lens: Theoretical and Methodological Considerations. Entreprenuership Theory and Practice, 33(5), 1079-1091.

Chirico, F., Sirmon, D. G., Sciascia, S., \& Mazzola, P. (2011). Resource Orchestration in Family Firms: Investigating How Entrepreneurial Orientation, Generational Involvement, and Participative Strategy Affect Performance. Strategic Entrepreneurship Journal, 5, 307-326.

Cooke-Davies, T. (2002). The "Real" Success Factors on Projects. International Journal of Project Management, 20, $185-190$.

Corfee-morlot, J., Marchal, V., Kauffmann, C., Kennedy, C., Stewart, F., Kaminker, C., \& Ang, G. (2012). Towards a Green Investment Policy Framework: The case of low carbon climate-resilient infrastructure.

Covin, J. G., \& Slevin, D. P. (1989). Strategic management of small firms in hostile and benign enviroments. Strategic Management Journal, 10(1), 75-87.

Covin, J. G., \& Wales, W. J. (2012). The Measurement of Entrepreneurial Orientation. Entrepreneurship: Theory and Practice, 36(4), 677-702.

Dai, C. X., \& Wells, W. G. (2004). An exploration of project management office features and their relationship to project performance. International Journal of Project Management, 22(7), 523-532.

Diamantopoulos, A. (1994). Modelling with LISREL: A guide for the uninitiated. Journal of Marketing Management, 10(1-3), 105-136. http://doi.org/10.1080/0267257X.1994.9964263

Eckhardt, J. T., \& Shane, S. a. (2003). Opportunities and Entreprenuership. Journal of Management, 29(3), 333-349.

Engwall, M. (2003). No project is an island: Linking projects to history and context. Research Policy, 32(5), 789-808. http://doi.org/10.1016/S0048-7333(02)00088-4

Ethiraj, S. K., Kale, P., Krishnan, M. S., \& Singh, J. V. (2005). Where do capabilities come from and how do they matter? A study in the software services industry. Strategic Management Journal, 26(1), 25-45.

Garver, M., \& Mentzer, J. (1999). Logistics research methods: employing structural equation modeling to test for construct validity. Journal of Business Logistics, 20(1), 33-57.

GOI. (2014) Presidential Regulation of Republic of Indonesia No. 79 Year 2014 on National Energy Policy (Peraturan Presiden Republik Indonesia No. 79 Tahun 2014 tentang Kebijakan Energi Nasional). The Government of Indonesia (GOI).

Hadaya, P., Cassivi, L., \& Chalabi, C. (2012). IT project management resources and capabilities: a Delphi study. 
International Journal of Managing Projects in Business, 5(2), 216-229.

Hair Jr., J. F., William, B. C., Babin, B. J., \& Anderson, R. E. (2014). Multivariate Data Analysis (Seventh Ed). Pearson Education Limited.

Helfat, C. E., Finkelstein, S., Mitchell, W., Peteraf, M., Singh, H., Teece, D., \& Winter, S. (2007). Dynamic Capabilities Understanding Strategic Change in Organizations (First Publ). Blackwell Publishing.

Henseler, G. W. Z. J. (2009). Inter-firm Network Capability: How It Affects Buyer-Supplier Perfromance. British Food Journal, 111(8), 794-810.

Hillson, D. (2003). Assessing organisational project management capability. Journal of Facilities Management, 2(3), 298-311.

Hitt, M. A., Ireland, D., Camp, M. S., \& Sexton, D. D. (2001). Strategic entrepreneurship: Entrepreneurial strategies for wealth creation. Strategic Management, 22(6/7), 479-491.

Hitt, M. A., Ireland, R. D., Sirmon, D. G., \& Trahms, C. A. (2011). Creating Value for Individuals, Organizations, and Society. Academy of Management Executive, (May), 57-75.

Human, G., \& Naudé, P. (2009). Exploring the relationship between network competence, network capability, and firm performance: a resource based perspective in an emerging economy. Management Dynamics, 18(1), 2-14.

Ireland, R. D., Hitt, M. A., \& Sirmon, D. G. (2003). A Model of Strategic Entrepreneurship: The Construct and its Dimensions. Journal of Management, 29(6), 963-989.

Jager, D. De, \& Rathmann, M. (2008). Policy instrument design to reduce financing costs in renewable energy technology projects.

Joskow, P. L. (1997). Restructuring, Competition and Regulatory Reform in the U.S. Electricity Sector. Journal of Economic Perspectives, 11(3), 119-138.

Jugdev, K., Mathur, G., \& Fung, T. S. (2007). Project management assets and their relationship with the project management capability of the firm. International Journal of Project Management, 25(6), 560-568.

Jugdev, K., \& Müller, R. (2005). A Retrospective Look At Our Evolving For Project Success. Project Management Journal, 36, 19-32. http://doi.org/10.1109/EMR.2006.261387

Jugdev, K., \& Thomas, J. (2002). Project Management Maturity Models: The Silver Bullets of Competitive Advantage? Project Management Journal, 33(4), 4-14.

Jurisch, M., \& Palka, W. (2014). Which capabilities matter for successful business process change? Business Process Management Journal, 20(1), 47-67.

Kale, P., Singh, H., \& Perlmutter, H. (2000). Lerning and Protection of Proprietary Assets in Strategic Alliances: Building Relational Capital. Strategic Management Journal, 3(21), 217-237.

Killen, C. P., Jugdev, K., Drouin, N., \& Petit, Y. (2012). Advancing project and portfolio management research: Applying strategic management theories. International Journal of Project Management, 30(5), 525-538.

Lee, C., Lee, K., \& Pennings, J. M. (2001). Internal capabilities, external networks, and performance: A study on technology-based ventures. Strategic Management Journal, 22(6-7), 615-640.

Ling, Y. Y., \& Lau, B. S. Y. (2002). A case study on the management of the development of a large-scale power plant project in East Asia based on design-build arrangement. International Journal of Project Management, 20(6), 413423.

Lumpkin, G. T., \& Dess, G. G. (1996). Clarifying the Entrepreneurial Orientation Construct and Linking It to Performance. The Academy of Management Review, 21(1), 135-172.

Miller, D. (1983). The Correlates of Entrepreneurship in Three Types of Firms,. Management Sciences, $29(7), 770$ - 791.

Minniti, M. (2008). The role of government policy on entrepreneurial activity: Productive, unproductive, or destructive? Entrepreneurship: Theory and Practice, 32(5), 779-790.

Mitrega, M., Forkmann, S., Ramos, C., \& Henneberg, S. C. (2012). Networking capability in business relationships Concept and scale development. Industrial Marketing Management, 41(5), 739-751.

Morris, P. (2013). Reconstructing Project Management Reprised: A Knowledge Perspective. Project Management Journal, 44(5), 6-23.

Morris, P., \& Jamieson, A. (2004). Translating Corporate Strategy Into Project Strategy - Realizing Corporate Strategy Into Project Strategy. Project Management Institute, Inc.

Oliver, C. (1997). Sustainable competitive advantage: Combining institutional and resource-based views. Strategic Management Journal, 18(9), 697-713.

Papke-Shields, K. E., Beise, C., \& Quan, J. (2010). Do project managers practice what they preach, and does it matter to project success? International Journal of Project Management, 28(7), 650-662. 
Peidong, Z., Yanli, Y., jin, S., Yonghong, Z., Lisheng, W., \& Xinrong, L. (2009). Opportunities and challenges for renewable energy policy in China. Renewable and Sustainable Energy Reviews, 13(2), 439-449.

Peng, M. W. (2003). Institutional Transitions and Strategic Choices. Academy of Management Review, 28(2), 275-296. http://doi.org/10.5465/AMR.2003.9416341

Peng, M. W., Sun, S. L., Pinkham, B., \& Chen, H. (2009). The Institution-Based View as a Third Leg for a Strategy Tripod. Academy of Management Perspectives, 23(3), 63-81.

Pich, M. T., Loch, C. H., \& Meyer, A. De. (2002). On uncertainty, ambiguity, and complexity in project management. Management Science, 48(8), 1008-1023.

Pinto, J. K., \& Winch, G. (2016). The unsettling of "settled science:" The past and future of the management of projects. International Journal of Project Management, 34(2), 237-245.

Pintz, P., \& Korn, A. (2005). Development of a Competitive Electricity Market in Indonesia. Energy Studies Review, $13(2), 56-70$.

Platje, J. (2008). "Institutional Capital" as a Factor of Sustainable Development-The Importance of an Institutional Equilibrium. Technological and Economic Development of Economy, 14(2), 144-150.

PLN. (2013). Independent Power Producers Business in PT PLN (Persero). PLN.

Polzin, F., Migendt, M., Täube, F. A., \& Flotow, P. Von. (2015). Public Policy Influence on Renewable Energy Investments - A Panel Data Study across OECD Countries. Energy Policy, 80, 98-111.

Rauch, A., Wiklund, J., Lumpkin, G. T., \& Frese, M. (2004). Entrepreneurial orientation and business performance: An assessment of past research and suggestions for the future. Entrepreneurship: Theory and Practice, 33(3), 761787.

Scott, W. R. (1987). The Adolescence of Theory Institutional. Administrative Science Quarterly, 32(4), 493-511.

Shane, S., \& Cable, D. (2002). Network Ties, Reputation, and the Financing of New Ventures. Management Science, 48(3), 364-381.

Shenhar, A. J., Dvir, D., Ofer, L., \& Maltz, A. C. (2001). Project Success: A Multidimensional Strategic Concept. Long Range Planning, 34, 699-725.

Shirokova, G. V, \& Sokolova, L. S. (2013). Exploring the antecedents of entrepreneurial orientation in Russian SMEs: the role of institutional environment ( $\mathrm{Vol} .1)$.

Silvius, G., Schipper, R., Planko, J., van den Brink, J., \& Kohler, A. (2012). Sustainability in Project Management (Gower e-Bo). Gower Publishing.

Sine, W. D., Haveman, H. A., \& Tolbert, P. S. (2005). Risky Business? Entrepreneurship in the New Independent-Power Sector. Administrative Science Quarterly, 50(2), 200-232.

Sirmon, D. G., Hitt, M. A., Ireland, R. D., \& Gilbert, B. A. (2011). Resource Orchestration to Create Competitive Advantage: Breadth, Depth, and Life Cycle Effects. Journal of Management, 37(5), 1390-1412.

Sirmon, D. G., Hitt, M., \& Ireland, R. (2007). Managing firm resources in dynamic environments to create value: Looking inside the black box. Academy of Management Review, 32(1), 273-292.

Svejvig, P., \& Andersen, P. (2015). Rethinking project management: A structured literature review with a critical look at the brave new world. International Journal of Project Management, 33(2), 278-290.

Teece, D. J. (2007). Explicating dynamic capabilities: The nature and microfoundations of (sustainable) enterprise performance. Strategic Management Journal, 28(13), 1319-1350.

Tracey, P., \& Phillips, N. (2011). Entreprenuership in Emerging Markets: Strategies for New Venture Creation in Uncertain Institutional Contexts. Management International Review, 51(1), 23-39.

Turner, J. R., Anbari, F., \& Bredillet, C. (2013). Perspectives on research in project management: the nine schools. Glob Bus Perspect, 1, 3-28.

Uzzi, B., \& Lancaster, R. (2003). Relational embeddedness and learning: the case of bank loan managers and their clients. Management Science, 49(4), 383-399.

Walter, A., Auer, M., \& Ritter, T. (2006). The impact of network capabilities and entrepreneurial orientation on university spin-off performance. Journal of Business Venturing, 21(4), 541-567.

Wiklund, J., \& Shepherd, D. (2003). Knowledge-based Resources, EO, and the Performance of Small and Medium-sized Businesses. Strategic Management Journal, 24(13), 1307-1314.

Winch, G. M. (2014). Three domains of project organising. International Journal of Project Management, 32(5), $721-$ 731.

Wustenhagen, R., \& Menichetti, E. (2012). Strategic choices for renewable energy investment: Conceptual framework and opportunities for further research. Energy Policy, 40(1), 1-10. 
Yamakawa, Y., Peng, M. W., \& Deeds, D. L. (2008). What Drives New Ventures to Internationalize from Emerging to Developed Economies. Entrepreneurship: Theory and Practice, 59-82.

Zeng, S. X., Xie, X. M., \& Tam, C. M. (2010). Relationship between cooperation networks and innovation performance of SMEs. Technovation, 30(3), 181-194.

Zwikael, O., Shimizu, K., \& Globerson, S. (2005). Cultural differences in project management capabilities: A field study. International Journal of Project Management, 23(6), 454-462. 